\title{
Selective eating: searching for clarity in complexity
}

\author{
Carol Smith ${ }^{1 *}$, Neil McLean², Julie McCormack ${ }^{1}$ \\ From 2014 ANZAED Conference: Driven Bodies Driven Brains \\ Fremantle, Australia. 22-23 August 2014
}

Selective Eating (SE) refers to those children who significantly restrict their eating, but demonstrate no apparent concerns about weight or shape. Typically children with SE eat a very limited range of foods, usually over a number of years. In severe cases of SE there is anecdotal evidence that the child's growth is affected, but more commonly parents report that the child's eating patterns result in marked family distress and conflict as well as impairment in social functioning. This category of eating disorders is diagnostically unclear, with no formal criteria, and a paucity of empirical research. This research set out to understand more clearly the nature of SE starting with investigation of the level of concern about the problem and associated demographic factors. An objective measure of SE was developed based on analysis of food diaries, which was crucial in both ongoing research and assessing this ill-defined problem. Finally psychological aspects of the problem were investigated by comparing children with SE with a control group. Parents of SE's were more stressed and also more involved with their child's eating. The children themselves often had a history of developmental issues such as gagging or sensory aversion, but also had an anxious temperament and behavioural difficulties when younger, and features of anxiety and particularly OCD when older. These results highlight the complexity in assessing and treating this phenomenon.

This abstract was presented in the Service Initiatives: Child and Adolescent stream of the 2014 ANZAED Conference.

\footnotetext{
Authors' details

${ }^{1}$ Eating Disorders Program, Specialised Child and Adolescent Mental Health Service, Department of Health in Western Australia, Perth, Australia.

${ }^{2}$ University of Western Australia, Perth, Australia.
}

Published: 24 November 2014

\footnotetext{
* Correspondence: carol.smith2@health.wa.gov.au

${ }^{1}$ Eating Disorders Program, Specialised Child and Adolescent Mental Health

Service, Department of Health in Western Australia, Perth, Australia

Full list of author information is available at the end of the article
}

doi:10.1186/2050-2974-2-S1-O53

Cite this article as: Smith et al:: Selective eating: searching for clarity in complexity. Journal of Eating Disorders 2014 2(Suppl 1):O53.
Submit your next manuscript to BioMed Central and take full advantage of:

- Convenient online submission

- Thorough peer review

- No space constraints or color figure charges

- Immediate publication on acceptance

- Inclusion in PubMed, CAS, Scopus and Google Scholar

- Research which is freely available for redistribution

Submit your manuscript at www.biomedcentral.com/submit

\section{Biomed Central}

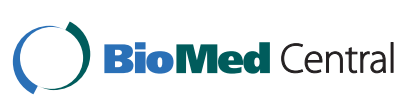

(c) 2014 Smith et al; licensee BioMed Central Ltd. This is an Open Access article distributed under the terms of the Creative Commons Attribution License (http://creativecommons.org/licenses/by/4.0), which permits unrestricted use, distribution, and reproduction in any medium, provided the original work is properly cited. The Creative Commons Public Domain Dedication waiver (http:// creativecommons.org/publicdomain/zero/1.0/) applies to the data made available in this article, unless otherwise stated. 